\title{
Factors Affecting the Quality of Outpatient Registration Service and Patient Satisfaction at the Community Health Center in Surakarta and Karanganyar, Central Java
}

\author{
Isnaini Qoriatul Fadhilah',2), Bhisma Murti²), Hanung Prasetya3) \\ 1)School of Health Polytechnics, Ministry of Health, Semarang \\ ${ }^{2)}$ Masters Program in Public Health, Universitas Sebelas Maret \\ 3)School of Health Polytechnics, Ministry of Health, Surakarta
}

\section{ABSTRACT}

Background: Patient Registration Place is the first service gate at a health service facility. Community health center as primary service providers and as a place for public services must provide satisfaction to customers. This study aims to determine the factors that influence the quality of services where outpatient registration and patient satisfaction in health centers. The purpose of this study is to measure and analyze the factors that influence the quality of outpatient registration services and satisfaction.

Subjects and Method: This was an analytic observational study with a cross-sectional design. The study was conducted in Surakarta and Karanganyar health centers, Central Java, from September to October 2019. A sample of 200 patients was selected by stratified random sampling. The dependent variable was patient satisfaction. The independent variables were the qualifications of the officer, tenure, employment status, patient education, patient income, type of payment, patient age, and patient quality. The data were collected by questionnaire. The data were analyzed by a multiple logistic regression run on Stata 13.

Results: : The quality of outpatient registration services improved with civil servant status $(\mathrm{OR}=$ 4.03; 95\% $\mathrm{CI}=1.83$ to $8.86 ; \mathrm{p}=0.001)$, patient education $\geq$ Senior high school $(\mathrm{OR}=0.27 ; 95 \%$ $\mathrm{CI}=0.14$ to $0.54 ; \mathrm{p}<0.001$ ), and BPJS insurance $(\mathrm{OR}=0.52 ; 95 \% \mathrm{CI}=0.26$ to $1.02 ; \mathrm{p}=0.058)$.
Patient satisfaction improved with education level of the officer (Diploma III) $(\mathrm{OR}=3.99 ; 95 \%$ $\mathrm{CI}=1.48$ to $10.68 ; \mathrm{p}=0.006$ ), tenure $\geq 12$ years $(\mathrm{OR}=4.52 ; 95 \% \mathrm{CI}=1.74$ to $11.75 ; \mathrm{p}=0.004)$, patient age $\geq 37$ years $(\mathrm{OR}=2.96 ; 95 \% \mathrm{CI}=1.27$ to $6.84 ; \mathrm{p}=0.011)$, and good service quality $(\mathrm{OR}=$ $3.42 ; 95 \% \mathrm{CI}=1.40$ to $8.35 ; \mathrm{p}=0.007$ ). Patient satisfaction decreased with patient education $\geq$ Senior high school $(\mathrm{OR}=0.35 ; 95 \% \mathrm{CI}=0.14$ to o.84; $\mathrm{p}=0.021$ ), income $\geq \operatorname{Rp~} 1,800,000(\mathrm{OR}=$ $0.39 ; 95 \% \mathrm{CI}=0.17$ to $0.92 ; \mathrm{p}=0.031)$, and BPJS insurance $(\mathrm{OR}=0.13 ; 95 \% \mathrm{CI}=0.05$ to 0.32 ; $\mathrm{p}<0.001)$.

Conclusion: The quality of outpatient registration services improves with civil servant status, patient education $\geq$ Senior high school, and BPJS insurance. Patient satisfaction improves with education level of the officer, tenure $\geq 12$ years, patient age $\geq 37$ years, and good service quality. Patient satisfaction decreases with patient education, income, and BPJS insurance.

Keywords: quality of patient registration services, patient satisfaction, medical records

\section{Correspondence:}

Isnaini Qoriatul Fadhilah, Masters Program in Public Health, Universitas Sebelas Maret. Jl. Ir. Sutami 36A, Surakarta 57126, Central Java. Email: isnainiqoriatul@gmail.com. Mobile: o89681918022

\section{Cite this as:}

Fadhilah IQ, Murti B, Prasetya H (2020). Factors Affecting the Quality of Outpatient Registration Service and Patient Satisfaction at the Community Health Center in Surakarta and Karanganyar, Central Java. J Health Policy Manage. 5(2): 92-102. https://doi.org/10.26911/thejhpm.2020.05.02.01

c() (i) (2) Journal of Health Policy and Management is licensed under a Creative Commons Journal of Health Policy and Management is licensed under a Creative
Attribution-Non Commercial-Share Alike 4.o International License. 


\section{BACKGROUND}

Community health center as a first level health care facility (FKTP) must have accurate data both on socio-demographic data and patient medical information data so the need for a medical record work unit at the community health center. Patient registration is part of the medical record unit. Patient Registration Place (TPP) is the first service gate at a health service facility. Outpatient Registration Place (TPPRJ) is the hospital's first service that plays an important role in giving a good first impression to patients. The waiting time at TPPRJ is one of the factors that determine the initial image of the hospital. Respondents who stated that the waiting time for outpatient registration in TPPRJ Sukoharjo General Hospital in the fast category were 51 people (53.7\%), while respondents who stated the waiting time in the long category were 44 people (46.3\%).

Respondents who said they were satisfied with the service were 50 people (52.6\%), while 45 people $(47.4 \%)$ were not satisfied with the service. The highest satisfaction in the discipline of officers and the lowest in the cleanliness of the waiting room and the speed of patient waiting time so that there is a significant relationship between waiting time for registration with patient satisfaction in TPPRJ Sukoharjo Regional Hospital (Dewi et al., 2015).

According to Goetz et al. (2015) ongoing quality improvement processes in the context of practice assessment, structure evaluation and care processes especially for patient safety are important. The results of his research indicate that implementing a quality management system also includes a process of continuous improvement that will have added value in providing systematic performance monitoring of primary health care practices.

Surakarta City is the most populous regency / city in Central Java with an area of $44.04 \mathrm{~km}^{2}$ and the population in 2017 of 558,732 people has 17 community health center. Participants of Surakarta City's Na- tional Health Insurance (JKN) are 456,896 people or $81.77 \%$ (Surakarta Health Office, 2018). JKN participants in Karanganyar Regency were 588,215 people out of 896,991 people or $65.57 \%$ (Karanganyar Health Office, 2018).

Based on Perpres Number 82 Article 17 of 2018, all Indonesian people are required to attend BPJS Health, meaning FKTP in this case must really provide excellent service from the initial patient registration until the patient goes home. Based on this background, researchers are interested in analyzing the factors that influence the quality of services in which outpatient registration and patient satisfaction are at the community health center.

\section{SUBJECTS AND METHOD}

\section{Study Design}

This was an analytic observational study with cross-sectional design. The study was conducted in Surakarta Center and Karanganyar community health centers, Central Java, from September to October 2019.

\section{Population and Sample}

The source population in this study was patients in the Surakarta and Karanganyar community health center. A sample of 200 patients was selected simple random sampling.

\section{Study Variables}

The dependent variables were quality of service and patient satisfaction. The independent variables include the qualifications of the medical record officer, the length of service of the medical record officer, the medical staff's employment status, the level of patient education, patient income, type of payment, patient age, and patient quality.

\section{Operational Definition of Variables Accreditation status was the result of the determination of the accreditation survey by the surveyors and decisions of the meeting of the accreditation independent institutions, as}


evidenced by the accreditation certificate, which consists of: primary, intermediate, basic, and not accredited. Qualifications of medical record officers are defined as officers who have completed formal education of at least Diploma 3 (D3) medical records and health information.

Educational Background was the status of formal education, which is pursued through a structured and tiered educational pathway. The data were collected by questionnaire. The measurement scale was categorical and transformed into dichotomous.

Patient income was a fixed income received each month calculated from the average amount of income received by patients from the formal and informal sectors, taking into account the Surakarta Regional Minimum Wage. The type of payment is defined as the participation of the patient in a health financing guarantee. The data were collected by questionnaire. The measurement scale was continuous and transformed into dichotomous.

Age was the number of years since the study subject was born until the time of data collection. The measuring instrument used was a questionnaire. The measurement scale was continuous and transformed into dichotomous.

\section{The quality of medical record services} was the assessment of patients in medical record services, especially in the outpatient registration section according to the Servqual method which consists of tangible, reliability, responsiveness, assurance, and empathy. The data were collected by questionnaire. The measurement scale was continuous and transformed into dichotomous.

Patient satisfaction was the feeling of pleasure of patients that comes from the comparison between the services obtained with expectations. The data were collected by questionnaire. The measurement scale was continuous and transformed into dichotomous.

\section{Data Analysis}

Univariate analysis is used to describe each dependent and independent variable. Data is grouped according to data types and entered in the frequency distribution table.

Bivariate analysis was used to determine the relationship between staffing status, patient education, and type of payment to the quality of outpatient registration services with the chi-square test. Bivariate analysis was also used to determine the relationship between officer qualifications, length of service of staff, patient age, patient education, patient income, type of patient payment, and quality of service to patient satisfaction with the chi-square test.

Multivariate analysis also explains the effect of staffing status, patient education, and type of patient payment on the quality of outpatient registration services analyzed by multiple logistic regression models. Multivariate analysis explains the influence of officer qualification status, length of service of the officer, patient age, patient education, patient income, type of patient payment, and quality of service on patient satisfaction analyzed by multiple logistic regression models. Univariate, bivariate, and multivariate analyzes were performed using the Stata 13 program.

\section{Research Ethic}

Research ethics include: informed consent, anonymity, confidentiality, and ethical clearance. Ethical clearance was obtained from the Health Research Ethics Commission Dr. Moewardi Hospital, Surakarta with No. Ethical Feasibility: 1.033/VIII/ HREC/2019.

\section{RESULTS}

\section{Sample Characteristics}

Table 1 show that the majority of study subjects were $\geq 37$ years old, totaling 136 people (68\%). 
The last education most of the patients were $<$ senior high schoo (SHS)l, as many as 135 (67.5\%). The majority of subjects' researches $<$ minimum wage are 127 people (65.5\%). Most of the subjects used the regular payment type of 105 people (52.5\%).

\section{Univariate analysis}

a. Univariate analysis of continuous data

The characteristics of 200 research subjects that are the research subjects are shown in table 1 with the following explanation. The minimum length of service for an outpatient registration officer is 1 year and the maximum is 37.78 years with an average value of 12.42 and a standard deviation of 10.04. The minimum age of the patient is 17 years and the maximum age is 37.78 years with an average value of 37.78 and a standard deviation of 13.12. The minimum income for patients is IDR 150,000 and the maximum income is IDR 10,000,000 with an average value of IDR $1,974,700$ and a standard deviation of IDR 1,4064,000. The minimum quality of service for outpatient registration is 54 and the maximum quality is 103 with an average value of 75.28 and a standard deviation of 11.22. The minimum patient satisfaction for outpatient registration services is 10 and the maximum satisfaction is 27 with an average value of 14.67 and a standard deviation of 2.63 .

\section{b. Univariate analysis of categorical data}

Table 2 explains that the majority of outpatient registration officers have D3 Medical Record qualifications, which is 107 (53.5\%) while the qualifications of officers who are not from D3 Medical Records are 93 (46.5\%). Most of the outpatient registration officers have staffing status instead of civil servant namely 122 (61\%) while the officers who have civil servant staffing status are 78 (39\%).

Most of the patients have education $<$ high school which is a number of 135 (67.5\%) while patients who have education $\geq$ high school are 65 (32.5\%). Patients who use the regular type of payment are 105 (52.5\%) while patients who use the BPJS type of payment are 95 (47.5\%).

\section{Table 1. Characteristics of continuous data samples}

\begin{tabular}{lccccc}
\hline Characteristics & n & Mean & SD & Minimum & Maximum \\
\hline Employee working period & 200 & 12.42 & 10.04 & 1 & 37 \\
Age (years) & 200 & 37.78 & 13.12 & 17 & 74 \\
Income (x Rp 10,000) & 200 & 197.47 & 140.64 & 15 & 1000 \\
Quality & 200 & 75.28 & 11.22 & 54 & 103 \\
Satisfaction & 200 & 14.67 & 2.63 & 10 & 27 \\
\hline
\end{tabular}

Table 2 Descriptions of the characteristics of categorical data samples

\begin{tabular}{llcc}
\hline \multicolumn{2}{c}{ Characteristics } & Frequency(n) & Percentage (\%) \\
\hline Officer Qualifications & Not D3 Medical Records & 93 & 46.5 \\
& D3 Medical Records & 107 & 53.5 \\
Employment status & Non civil servant & 122 & 61 \\
\multirow{3}{*}{ Patient education } & Civil servant & 78 & 39 \\
\multirow{2}{*}{ Type of payment } & S SHS & 135 & 67.5 \\
& S SHS & 65 & 32.5 \\
& Regular & 105 & 52.5 \\
& BPJS & 95 & 47.5 \\
\hline
\end{tabular}


Fadhilah et al./ Factors Affecting the Quality of Outpatient Registration

3. Bivariate Analysis

Table 3. Bivariate analysis of factors influencing health service quality

\begin{tabular}{|c|c|c|c|c|c|c|c|c|c|}
\hline \multirow{3}{*}{$\begin{array}{l}\text { Independent } \\
\text { Variable }\end{array}$} & \multicolumn{4}{|c|}{ Service Quality } & \multirow{2}{*}{\multicolumn{2}{|c|}{ Total }} & \multirow{3}{*}{ OR } & \multirow{3}{*}{ (95\%) CI } & \multirow{3}{*}{$\mathrm{p}$} \\
\hline & \multicolumn{2}{|c|}{ Poor } & \multicolumn{2}{|c|}{ Good } & & & & & \\
\hline & $\mathrm{n}$ & $\%$ & $\mathrm{n}$ & $\%$ & $\mathrm{n}$ & $\%$ & & & \\
\hline \multicolumn{10}{|l|}{ Employment Status } \\
\hline Not civil servant & 51 & 41.8 & 71 & 58.2 & 122 & 100 & 4.88 & 2.20 to 11.60 & $<0.001$ \\
\hline Civil servant & 10 & 12.8 & 68 & 87.2 & 78 & 100 & & & \\
\hline$<$ Senior high school & 27 & 20 & 108 & 80 & 135 & 100 & 0.23 & 0.11 to 0.46 & $<0.001$ \\
\hline $\begin{array}{l}\geq \text { Senior high school } \\
\text { Payment type }\end{array}$ & 34 & 52.3 & 31 & 47.7 & 65 & 100 & & & \\
\hline Regular & 22 & 20.9 & 83 & 79.1 & 105 & 100 & 0.38 & 0.19 to 0.74 & 0.002 \\
\hline BPJS & 39 & 41.1 & 56 & 58.9 & 95 & 100 & & & \\
\hline
\end{tabular}

Table 4. Bivariate analysis of factors that influence patients satisfaction

\begin{tabular}{|c|c|c|c|c|c|c|c|c|}
\hline \multirow{3}{*}{ Independent Variable } & \multicolumn{4}{|c|}{ Patient Satisfaction } & \multicolumn{2}{|c|}{ Total } & \multirow{3}{*}{ OR } & \multirow{3}{*}{$\mathbf{p}$} \\
\hline & \multicolumn{2}{|c|}{ Low } & \multicolumn{2}{|c|}{ High } & \multirow[b]{2}{*}{$\mathbf{n}$} & \multirow[b]{2}{*}{$\%$} & & \\
\hline & $\mathbf{n}$ & $\%$ & $\mathbf{n}$ & $\%$ & & & & \\
\hline \multicolumn{9}{|l|}{ Employee Qualification } \\
\hline Not D3 Medical Records & 40 & 43 & 53 & 57 & 93 & 100 & 2.92 & 0.006 \\
\hline Not D3 Medical Records & 22 & 20.6 & 85 & 79.4 & 107 & 100 & & \\
\hline \multicolumn{9}{|l|}{ Working period } \\
\hline$<12$ years & 37 & 47.4 & 41 & 52.6 & 78 & 100 & 3.50 & $<0.001$ \\
\hline$\geq 12$ years & 25 & 20.5 & 97 & 79.5 & 122 & & & \\
\hline \multicolumn{9}{|l|}{ Age } \\
\hline$<37$ years & 34 & 53.1 & 30 & 46.9 & 64 & 100 & 4.37 & $<0.001$ \\
\hline$\geq 37$ years & 28 & 20.6 & 108 & 79.4 & 136 & 100 & & \\
\hline \multicolumn{9}{|l|}{ Education } \\
\hline$<$ SHS & 24 & 17.8 & 111 & 82.2 & 135 & 100 & 0.15 & $<0.001$ \\
\hline$\geq$ SHS & 38 & 58.5 & 27 & 41.5 & 65 & 100 & & \\
\hline \multicolumn{9}{|l|}{ Income } \\
\hline$<\operatorname{Rp} 1,800,000$ & 28 & 22 & 99 & 78 & 127 & 100 & 0.32 & 0.003 \\
\hline$\geq \operatorname{Rp} 1,800,000$ & 34 & 46.6 & 39 & 53.4 & 73 & 100 & & \\
\hline \multicolumn{9}{|l|}{ Payment Type } \\
\hline Regular & 12 & 11.4 & 93 & 88.6 & 105 & 100 & 0.12 & $<0.001$ \\
\hline BPJS & 50 & 52.6 & 45 & 47.4 & 95 & 100 & & \\
\hline \multicolumn{9}{|l|}{ Quality } \\
\hline$<75$ poor & 35 & 57.4 & 26 & 42.6 & 61 & 100 & $5 \cdot 58$ & $<0.001$ \\
\hline$\geq 75$ good & 27 & 19.4 & 122 & 80.6 & 139 & 100 & & \\
\hline
\end{tabular}


Fadhilah et al./ Factors Affecting the Quality of Outpatient Registration

Table 5 and 6 showed the results of multiple logistic regression. Multivariate analysis explains the effect of more than one independent variable on one dependent variable. The quality dependent variable for the independent variable is employment status, edu- cation and type of payment. In the dependent variable satisfaction for the independent variable was officer qualification, years of service, age, education, income, type of payment, and service quality.

\section{Multivariate Analysis}

a. Multiple Logistic Regression Analysis

Table 5. The results of multiple logistic regression on the factors associated with health service quality

\begin{tabular}{lccc}
\hline Independent Variable & OR & 95\% CI & p \\
\hline Employment Status (Civil Servant) & 4.03 & 1.83 to 8.86 & 0.001 \\
Patient education ( $\geq$ SHS) & 0.27 & 0.14 to 0.54 & $<0.001$ \\
Type of payment(BPJS) & 0.52 & 0.26 to 1.02 & 0.058 \\
N observation= 200 & 200 & & \\
Log likelihood = -102.71 & & & \\
$\mathrm{R}^{2}=16.5 \%$ & & & \\
$\mathrm{p}<0.001$ & & & \\
\hline
\end{tabular}

The quality of outpatient registration services improved with civil servant status $(\mathrm{OR}=4.03$; 95\% $\mathrm{CI}=1.83$ to $8.86 ; \mathrm{p}=0.001$ ), patient education $\geq$ Senior high school $(\mathrm{OR}=0.27$; 95\% $\mathrm{CI}=0.14$ to $0.54 ; \mathrm{p}<0.001)$, and BPJS insurance $(\mathrm{OR}=0.52 ; 95 \% \mathrm{CI}=0.26$ to 1.02 ; $\mathrm{p}=0.058$ ). Patient satisfaction improved with education level of the officer (Diploma III) $(\mathrm{OR}=3.99 ; 95 \% \mathrm{CI}=1.48$ to $10.68 ; \mathrm{p}=$ o.0o6), tenure $\geq 12$ years $(\mathrm{OR}=4.52 ; 95 \% \mathrm{CI}=$ 1.74 to $11.75 ; \mathrm{p}=0.004$ ), patient age $\geq 37$ years $(\mathrm{OR}=2.96 ; 95 \% \mathrm{CI}=1.27$ to $6.84 ; \mathrm{p}=$ o.011), and good service quality (OR= 3.42; 95\% $\mathrm{CI}=1.40$ to $8.35 ; \mathrm{p}=0.007$ ).

Patient satisfaction decreased with patient education $\geq$ Senior high school $(\mathrm{OR}=$ $0.35 ; 95 \% \mathrm{CI}=0.14$ to $0.84 ; \mathrm{p}=0.021)$, income $\geq \mathrm{Rp} 1,800,000(\mathrm{OR}=0.39 ; 95 \% \mathrm{CI}=$ 0.17 to $0.92 ; \mathrm{p}=0.031$ ), and BPJS insurance $(\mathrm{OR}=0.13 ; 95 \% \mathrm{CI}=0.05$ to $0.32 ; \mathrm{p}<0.001)$.

Table 6. The results of multiple logistic regression on the factors associated with patients satisfaction

\begin{tabular}{lccc}
\hline Independent Variable & OR & 95\% CI & p \\
\hline Employee status (D3 RM) & 3.99 & 1.48 to 10.68 & 0.006 \\
Working period ( $\geq$ 12 years) & 4.52 & 1.74 to 11.75 & 0.004 \\
Age ( $\geq$ 37 year) & 2.96 & 1.27 to 6.84 & 0.011 \\
Education ( $\geq$ SHS) & 0.35 & 0.14 to 0.84 & 0.021 \\
Income ( $\geq$ Rp 1,800,000) & 0.39 & 0.17 to 0.92 & 0.031 \\
Payment type (BPJS) & 0.13 & 0.05 to 0.32 & $<0.001$ \\
Quality (Good) & 3.42 & 1.40 to 8.35 & 0.007 \\
n observation $=200$ & & & \\
Log likehood $=-71.89$ & & & \\
$\mathrm{R}^{2}=41.9 \%$ & & & \\
p $<$ 0.001 & & & \\
\hline
\end{tabular}


DISCUSSION

1. The effect of employment status of medical record officers on the quality of health services

The results of the logistic regression analysis show that there is a positive relationship between the staffing status of the officers and the quality of the services where the outpatient registration is. Officers with civil servant staffing status have a logodd (possibility) to provide 4.03 service quality units better than officers with non-civil servant staffing status.

The results of this study are supported by $\mathrm{Lu}$ et al. (2016) and Roland et al. (2015) which states that the addition of incentives will also affect the quality of work of doctors in providing services. Adding a doctor's incentive will spur the maximum performance issued by the doctor which in this case will produce maximum ability to him and have an impact on service to patients.

The difference in the status of health workers who are not civil servant and civil servant located in the welfare of the income earned, where income and civil servant income is better than non-civil servant. Based on some of the descriptions above, it can be concluded that there is an influence between the staffing status of medical record officers on the quality of TPPRJ services so that the results of this study can be said to be in line with previous study.

\section{The effect of patient education on the quality of health services}

The results of the logistic regression study showed that there was a negative relationship between the level of patient education $(\mathrm{OR}=$ $0.27 ; 95 \% \mathrm{CI}=0.14$ to $0.54 ; \mathrm{p}<0.001$ ) with the quality of care at the place of outpatient registration. Patients with high school education have a logodd assessment of service quality of 1.29 units lower than patients with education $<$ high school.

This is also in line with the research of Abraham et al. (2015) which states that one of the factors that influence the quality of health services is the education of patients. Patients with a high level of education have higher hopes and desires than a low level of education. High expectations will tend to make patients dissatisfied with health services. A person or community with a higher level of education cannot adjust expectations according to the conditions of health care facilities (hospitals) so that services with higher quality services are needed so that they are more satisfied. Whereas patients with low levels of education have low expectations so they can adjust expectations according to hospital conditions and receive what services are provided (Al Fraihi et al., 2016).

\section{The effect of types of patient pay- ments on the quality of health services}

The results of the logistic regression analysis showed that there was a positive relationship between the types of patient payments and the quality of services at the community health center outpatient registration. Patients with this type of payment using BPJS have a logodd of service quality assessment of 0.52 units lower than patients with a type of general payment (fee for service). A study by Utami et al. (2017) shows that differences in the financing system affect differences in the quality of health services and those also have impacts on differences in patient satisfaction.

\section{The effect of employee qualifications on patient satisfaction}

The results of logistic regression analysis showed that there was a positive relationship between the qualifications of officers and patient satisfaction. Officers with D3 Medical Record qualifications have a logodd satisfaction of 3.99 units higher than the qualifications of officers not from D3 Medical Records. The results of this study are also supported by Hemadeh et al. (2019), which explains that the competency of health service providers in this case doctors and nurses 
can affect patient satisfaction. The fact is that patients who consider an incompetent doctor or nurse have a greater chance of being dissatisfied.

The competency of health workers is very closely related to the qualifications of health workers, which according to the Regulation of the Minister of Health of the Republic of Indonesia Number 4 of 2019 to carry out health service activities carried out by health workers in accordance with their competence and authority. Outpatient registration place is part of the medical record work unit where one of the competencies of the medical recorder.

Registering all visits in health care facilities (registration of outpatients and inpatients) for that officer who serves at the place of outpatient registration should have a minimum qualification of D3 Medical Record.

\section{The effect of the working period of the employee on the patient satis- faction}

The results showed that there was a relationship between the length of service of the officer and patient satisfaction. Officers with a service period of $\geq 12$ years have a logodd of satisfaction of 4.52 units higher than officers with a service period of $<12$ years.

This is in line with the results of study by McMichael and Healy (2017) which states that the longer the doctor's working period, the more skills and knowledge they will have. Patients will feel satisfied if treated by doctors with adequate skills and knowledge. In addition, the length of service of the doctor will increase the ability in therapeutic communication that can explore the wants and needs of patients. This is also balanced with patients who tend to provide low satisfaction due to the lack of patient distrust of health professionals who are less professional (Zhang et al., 2019).

\section{The effect of patient age on the patient satisfaction}

The results showed that there was a relationship between patient age and registration service satisfaction. Patients aged $\geq 37$ years had a higher logodd satisfaction of 2.96 units than patients aged $<37$ years.

The results of this study are also supported by research by Abraham et al. (2015) which states that there is a significant relationship between patient age and patient satisfaction. Patients aged 35 years and over assume that service providers are able to provide quality services and meet the needs of patients so that it affects the high level of satisfaction.

This is in line with the results of Kurniawan et al. (2019) which states that patients with age $\geq 35$ years have a higher level of satisfaction than patients with age $<35$ years. This is due to the fact that patients who visit the Community health center are mostly old, where there is deterioration in the structure and function of organs, so that people who have an older age make use of health services more than they do at a young age. In addition, in general, people with old age tend to be more open in nature so that their demands and expectations are lower than younger patients (Oroh et al., 2014).

\section{The effect of patient education on the patient satisfaction}

The results showed that there was a relationship between patient education and satisfaction with registration health service. Patients with education $\geq$ Senior high school had a lower satisfaction logodd of 0.35 units than patients with $<$ Senior high school education.

The results of the study of Abraham et al. (2015) and Mohamed et al. (2015), states that there is a significant effect between level of education on patient satisfaction. 
Patients with higher education levels tend to be more demanding and criticize more if the services received are felt to be unsatisfactory and not as expected. This will affect the level of patient satisfaction. Unlike someone with a low level of education, he tends to receive more and feel satisfied with the services provided because he does not know what he needs.

\section{The effect of patient income on the patient satisfaction}

The results showed that there was a relationship between patient income and service satisfaction at the place of outpatient registration. Patients with income $\geq \operatorname{Rp} 1,800,000$ have a lower logodd satisfaction of 0.39 units than patients with income $<\mathrm{Rp} 1,800,000$.

The results of this study are in line with Zun et al. (2018), which states that patients with low income are influential factors in determining satisfaction levels. Groups that have low incomes are more easily satisfied with the services provided by the Clinic. High incomes have higher service needs so the ability of service providers to provide the services needed in accordance with patient expectations is very important and effective in increasing patient satisfaction.

The results of this study are not in line with Subait et al. (2016), which shows the results that the level of patient income does not affect patient satisfaction. A person's perception is not only influenced by income, but can also be influenced by other factors that might affect one's perception of health services.

\section{Effect of payment type on patient satisfaction}

The results showed that there was a relationship between the types of patient payments and service satisfaction at the place of outpatient registration. Patients with BPJS type of payment had lower satisfaction logodd of -0.13 units than patients with non BPJS type of payment.

The results of the study were also supported by Kurniawan et al. (2019) which states that patients who use National Health Insurance financing $(\mathrm{JKN})$ have lower satisfaction compared to patients who use this type of general payment.

This is not in line with a study by Shi et al. (2015) which states that patients who are not insured have a higher level of satisfaction than patients who use health insurance. The cause of this is the difference in treatment where patients who pay independently pay more attention to their needs and complaints.

\section{The effect of service quality on patient satisfaction}

The results showed that there was a relationship between service quality and service satisfaction at the place of outpatient registration. Good service quality $(\geq 75)$ has a higher satisfaction logodd of 3.42 units than poor service quality $(<75)$. Satisfaction is influenced by service quality, where service quality according to Servqual theory is influ enced by five aspects namely tangibles, reliability, responsiveness, assurance, empathy. Complete and quality physical facilities will help provide satisfaction for service users.

The results of this study are also supported by Fang(2019), which shows that staff attitudes and comfort of health facilities are important in patient satisfaction. The attitude and comfort of health facilities is part of the quality of service (Grondahl et al., 2018).

According to Cong et al. (2014) empirically improving the quality of service affects patient satisfaction. Improved service quality in three dimensions of service quality, namely tangible, accessibility to health services as well as medical behavior and ethics affect patient satisfaction. 


\section{AUTHOR CONTRIBUTION}

Isnaini Qoriatul Fadhilah is the main researcher who played a role in collecting data and wrote the manuscript. Bhisma Murti played a role in developing ideas, study designs, and did data analysis. Hanung Prasetya played a role in compiling the research framework and suggesting the materials for the discussion.

\section{CONFLICT OF INTEREST}

There is no conflict of interest in this study.

FUNDING AND SPONSORSHIP

This study is self-funded.

\section{ACKNOWLEDGEMENT}

The researchers would like to thank the Health Office, Surakarta Health Center, and Karanganyar Health Center for allowing this study to be carried out. Thank you to all respondents who had been willing and cooperative to become subjects of the study.

\section{REFERENCE}

Abraham A, Olumodeji D, Oluwole E (2015). Influence of socio demographic variables nursing care i on patient's satisfaction with quality of teaching hospitals in northern Nigeria. Int $\mathrm{J}$ Med Sci Public Health 1(3): 18-24.https://doi.org/10.22271/ijmhr.

Al Fraihi KJ, Latif SA (2016). Evaluation of outpatient service quality in Eastern Saudi Arabia: Patient's expectations and perceptions. Saudi Medical Journal, 37(4): 420-428. https://doi.org/10.15537/smj.2016.4.1483

Dewi A, Astuti R, Werdani K (2015). Hubungan waktu tunggu pendaftaran dengan kepuasan pasien di Tempat Pendaftaran Pasien Rawat Jalan (TPPRJ) RSUD Sukoharjo (The relationship between waiting time for registration with patient satisfaction at the Outpatient Registration Place (TPPRJ)
Sukoharjo District Hospital). Retrieved from http://eprints.ums.ac.id/36185/.

Dinas Kesehatan Karanganyar (2018). Profil kesehatan tahun 2017 (Health profile for 2017). Retrieved from http://opendata.karanganyarkab.go.id/dataset/profil-kesehatan-tahun-2017.

Dinas Kesehatan Kota Surakarta (2018). Profil kesehatan Kota Surakarta tahun 2017 (Surakarta health profile in 2017). Retrieved from www.dinkes.surakarta.go.id.

Fang J, Liu L, Fang P (2019). What is the most important factor affecting patient satisfaction: A study based on gamma coefficient. Patient Preference and Adherence, 13:515-525. https://doi.org/10.2147/PPA.S197015

Goetz K, Hess S, Jossen M, Huber F, Rosemann T, Brodowski M, Szecsenyi J (2015). Does a quality management system improve quality in primary care practices in Switzerland? A longitudinal study. BMJ Open: 5(4). https://doi.org/10.1136/bmjopen-2014-007443.

Grondahl VA, Kirchhoff JW, Andersen KL, Sorby LA, Andreassen HM, Skaug EA, Helgesen AK (2018). Health care quality from the patients' perspective: A comparative study between an old and a new, high-tech hospital. J Multidiscip Health care 11, 591-60o.https://doi.org/10.2147/JMDH.S176630

Hemadeh R, Hammoud R, Kdouh O, Jaber T, Ammar L (2019). Patient satisfaction with primary healthcare services in Lebanon. International Journal of Health Planning and Management, 34(1): e423-e435. https://doi.org/10.1002/hpm.2659

Kurniawan HD, Tamtomo D, Murti B (2019). Contextual effect of community health center on patient satisfaction of health care service in Ngawi, East Java. J Health Policy Manage. 4(1): 23-30. 
Fadhilah et al./ Factors Affecting the Quality of Outpatient Registration

https://doi.org/10.26911/thejhpm.2019.04.01.03.

Lu Y, Hu XM, Huang XL, Zhuang XD, Guo, Feng LF, Hao YT (2016). Job satisfaction and associated factors among health care staff: A cross-sectional study in Guangdong Province, China. BMJ Open, 6(7). https://doi.org/10-1136/bmjopen-2016-011388

McMichael C, Healy J (2017). Health equity and migrants in the Greater Mekong Subregion. Global Health Action, 10. https://doi.org/10.1080/16549716-2017.1271594

Mohamed EY, Sami W, Alotaibi A (2015). Patients' satisfaction with primary health care centers' services, majmaah, Kingdom of Saudi of Saudi Arabia. Int J Med Sci Public Health 9(2): 159-165. https://doi.org/10-12816/o024113

Oroh ME, Rompas S, Pondaag L (2014). Faktor-faktor yang berhubungan dengan tingkat kepuasan pasien rawat inap terhadap pelayanan keperawatan di ruang interna RSUD Noongan (Factors related to the level of satisfaction of inpatients with nursing services in the internal space of Noongan Regional Hospital). Retrieved from https://ejournal.unsrat.ac.id/index.php/jkp/article/view/5220

Peraturan Presiden Republik Indonesia (2008). Peraturan Presiden Republik Indonesia Nomor 82 Tahun 2018 tentang Jaminan Kesehatan. Retrieved from https://jdih.kemenkeu.go.id/fullText/2018/82TAHUN2018PERPRES.pdf.

Roland M, Dudley RA (2015). How financial and reputational incentives can be used to improve medical care. Health Servi- ces Research, 50: 2090-2115. https://doi.org/10.1111/1475-6773.12419

Shi L, Lee DC, Liang H, Zhang L, Makinen $\mathrm{M}$, Blanchet N, Wu S (2015). Community health centers and primary care access and quality for chronically-ill patients - A case-comparison study of urban Guangdong Province, China. Int J Equity Health, 14(1). https://doi. org/10.1186/-12939-015-0222-7

Utami YT, Tamtomo D, Sulaeman ES (2017). Patient characteristics, financing type, accreditation status, and quality of health services at community health center, Surakarta. J Health Policy Manage, 2(1), 79-90. https://doi.org/10.26911/thejhpm.2017.01.02.07

Subait AA, Ali A, Alsammahi, Aleesa M, Alkashan S, Alsalem M, Aldahash A, Alfayez W, Metwally AE (2016). Perception and level of satisfaction of patients seeking dental care: A crosssectional study in a major healthcare center in Saudi Arabia. J Dent Health Oral Disord Ther. Retrieved from https://www.researchgate.net/publication/307389794

Zhang T, Ren J, Zhang X, Max W (2019). Medical and socio-demographic characteristics associated with patientperceived continuity of primary care: A cross-sectional survey in Hangzhou, China. Int J Health Plan M: 2967. https://doi.org/10.1002/hpm .2967

Zun AB, Ibrahim MI, Hamid AA (2018). Level of satisfaction on service quality dimensions based on servqual model among patients attending 1 Malaysia Clinic in Kota Bharu, Malaysia. Oman Medical Journal, 33(5): 416-422. https://doi.org/10.5001/omj.2018.76 